\title{
DRINK DRIVERS AND THE COURT PROCESS IN HOBART: A SUMMARY FOR 1000 OFFENDERS
}

\author{
by L.J. Wood \\ (with nineteen tables and one text-figure)
}

W00D, L.J., 1990 (31:x): Drink drivers and the court process in Hobart: a summary for 1()()() offenders. Pap Proc R. Soc Tasm. 124(1): 13-25. https://doi.org/10.26749/rstpp.124.1.13 ISSN 0080-4703. Department of Geography and Environmental Studies, University of Tasmania, GPO Box 252C, Hobart, Tasmania. Australia 7001.

The paper examines the personal characteristics, previous drink driving records, entry to the courts and court decisions for 100() offenders convicted in the Hobart Courts of Petty Sessions for alcohol-related driving oflences. It is shown that southern Tasmania has a very high rate of recidivism, that a large proportion chose legal representation and that the sentences of individual magistrates vary substantially even when a large number of lactors are held constant. It is suggested that solicitors use adjournments to steer clients towards particular magistrates and some options for review of the current system are outlined.

Keywords: drink driving, recidivism, court sentences.

\section{INTRODUCTION}

Analyses of crime are commonly frustrated by a lack of data. Official statistics (for example, ABS 1986) give broad overviews but are of limited value for detailed investigations of specific offences or types of offenders. Authorities with access to information, the police, road safety, prison and probation services, and the courts, rarely have the resources to produce more than gross summaries. Yet detailed examinations are important for at least two reasons. First, knowledge of offender characteristics is vital for the design and implementation of crime reduction strategies. Second, court sentences need to be scrutinised in order to identify any apparent disparities. It has been claimed that the courts "... want statistical information on their current sentencing practices" (Lovegrove 1987: 211). In noting that the major part of police effort and lower court time is probably spent on traffic matters, a Hobart magistrate claimed that, in Tasmania, "... there has been no effective monitoring of this tremendous expenditure of public time and resources" (Sikk 1985: 156).

This paper aims to fill part of the gap. It focusses on the most common offence treated in Tasmanian courts, drink driving, of which well over 4000 cases per annum are heard (ABS 1986). Detailed studies of drink driving, particularly examining the effects of random breath testing (RBT), are available for some mainland states (for example, Cashmore 1985), but material for Tasmania is sparse. Madden (1986) has provided a brief outline of the introduction of RBT to the state. Wood has examined variations in offender rates and penalties between Hobart suburbs (1987), in offender rates for local government areas (1989a) and in court decisions between the three benches that comprise the Tasmanian lower court system (1989b) .

\section{DATA SOURCES AND AIMS}

For this study, data were collected with the assistance of the Tasmanian Police Department. From January 1987 , a set of details was recorded for slightly over 1000 drink driving offenders apprehended in southern Tasmania and eventually convicted by the Hobart-based Court of Petty Sessions. Details included name, age, sex, place of residence, place and date of arrest, occupation, blood alcohol concentration (BAC), ancillary offences (i.e. offences other than drink driving with which the offender was simultaneously charged), presence or absence of legal representation, number of adjournments before sentence, presiding magistrate, date of conviction and court penalty. Data were cross-checked by reference to press reports of drink driving convictions which include name, address, age, BAC and penalty for all offenders. Police and press records rarely differed, although obviously not all details could be checked. Information on the previous drink driving convictions of each offender (generally referred to below as priors) was collected by the author from file cards maintained by the Breathalyser Unit.

The data problems need to be acknowledged. First, the original intention was to have data collected for the first 1000 offenders to be convicted from January 
1987. Through work pressure, the police were not able to met this am and there were some periods when details were not recorded. There is no means of testing for bias in police recording but neither is there re ason to suspect it. Second, al though the record of priors as begun in the early 1970's, there were some indications that it was not totally accurate. This applies particularly for offences committed in other police jurisdictions. Errors are likely to be on the side of under recording. Third, as with any laborious recording exercise, some delails were missing and not retrievable.

Despite these drawbacks, the data provide information that has not previously been avalable for Tasmania. The initial list was pruned to 1000 by including only the last offence of the few individuals who appeared more than once during the data collection period and randomly deleting four others.

Data are presented under four headings: personal characteristics; prior records and the characteristics of the offence that brought offenders into the sample; entry to the court system and, finally, the court decision. Some parallels are drawn with mainland studies. The emphasis is on description rather than multiple cross-tabulations, in the belief that there is a need for baseline information. However, particular weight is given to prior records and the role of the individual magistrate ..... two factors shown to be of major importance in mainland studies.

\section{PERSONAL CHARACTERISTICS OF OFFENDERS}

Young, unskilled or unemployed males are heavily represented in Australian drink driving conviction statistics (Homel 1981). This statement certainly applies to Tasmania where $85.5 \%$ of the sample was male. Figures for NSW from 1977 to 1983 showed in excess of $93 \%$ of convicted drink driving offenders to be male (Cashmore 1985). The slightly tower figure for Tasmania may reflect a randomising influence of RBT (introduced to the state in 1983). Cashmore also shows that $39.8 \%$ of convicted offenders in NSW in 1983 were men under the age of 25 . The age breakdown for Tasmania shows 42 . $3 \%$ of the sample in this category (table 1 ).

In terms of occupation, $43.1 \%$ of the sample were either unemployed or in the "Labourers and Related Workers" category (table 2). By contrast. the highstatus managerial, administrative, professional, and paraprofessional occupations, employing $30.3 \%$ of Hobart's labour force in 1986 (Kennedy et al. 1989), provided only $9.2 \%$ of offenders.
TALEI

Age and Sex Composition of 16900 Convicted Drink Driving Offenders. Hobart 1987

\begin{tabular}{|c|c|c|c|c|}
\hline \multirow[t]{2}{*}{$A g e^{\prime}$} & \multicolumn{2}{|c|}{ Minle } & \multicolumn{2}{|c|}{ temale } \\
\hline & No. & $\%$ & 80. & $\%$ \\
\hline$<20$ & 131 & 15,3 & 16 & 110 \\
\hline 20)-24 & 231 & 270 & 47 & 32,4 \\
\hline $25-20$ & 169 & 19.8 & 33 & 22.8 \\
\hline 30.34 & 98 & 11.4 & 22 & 15.2 \\
\hline 35.39 & 69 & 8.1 & 13 & 90 \\
\hline $40-44$ & 68 & 8.0 & 8 & 5.5 \\
\hline $45-49$ & 39 & 4.6 & 5 & 3.5 \\
\hline $50-.54$ & 26 & 3.0 & 0 & () \\
\hline 5.59 & 12 & 1.4 & 1 & 0.7 \\
\hline $60-64$ & 5 & 0.6 & () & 0 \\
\hline $65-69$ & 5 & 0.6 & 0 & () \\
\hline$>69$ & 1 & 0.1 & 0 & () \\
\hline Total & 854 & 100.0 & 145 & 1000 \\
\hline
\end{tabular}

TABLE 2

Occupations of 1000 Convicted Drink Driving Offenders, Hobart 1987

\begin{tabular}{|c|c|c|c|}
\hline Occupation & No. & $\%$ & $\begin{array}{c}\% \\
\text { represented } \\
\text { by a } \\
\text { solicitor }\end{array}$ \\
\hline Managerial/admin. & 39 & 3.9 & 87.2 \\
\hline Professional & 23 & 2.3 & 73.9 \\
\hline Para-professionaltechnical & 34 & 3.4 & 70.1 \\
\hline Trades and related & 121 & 12.1 & 60.3 \\
\hline Clerical & 54 & 5.4 & 59.3 \\
\hline Sales and personal services & 92 & 9.2 & 63.0 \\
\hline Plant operators & 58 & 5.8 & 79.3 \\
\hline Labourers and related & 230 & 23.0 & 53.9 \\
\hline Unempleyed & 201 & 20.1 & 56.2 \\
\hline House duties & 31 & 3.1 & 48.4 \\
\hline Retired pensioners & 12 & 1.2 & 83.3 \\
\hline Other pensioners & 34 & 3.4 & 52.9 \\
\hline Student & 27 & 2.7 & 55.6 \\
\hline Defence forces & 3 & 0.3 & 66.7 \\
\hline Not stated & 41 & 4.1 & 73.6 \\
\hline Total & 10000 & 100.0 & 67.4 \\
\hline
\end{tabular}


The factors that lead to a strong representation of young, unskil led/unemployed males in drink driving convictions have been subject to some debate. One perspective is that high-status groups "... are more deterred by the threat of legal and informal punishment" (Andenaes 1978, in Homel 1986: 134). By contrast. Homel suggests that the overrepresentation "... may, to a considerable degree, be a function of selective police practices" (1986:12).

A factor that has received little attention in the literature is the home location of offenders. Previous work in Hobart has shown that newer, peripheral, public housing estates have very high offender rates (Wood 1987). Changed census boundaries make direct comparisons impossible. However, the nine suburbs in which more than $20 \%$ of housing was public rental in 1986 contained $16.9 \%$ of the city's population but $42.7 \%$ of the offenders resident in the metropolitan area. By contrast, the nine suburbs with less than $1 \%$ public housing had comparable figures of $27.4 \%$ and $32.2 \%$.

This is not to suggest that public housing per se is a predictor of likelihood to offend. Rather, such areas tend to contain clusters of people with high scores on various risk factors (low incomes, high proportions unskilled or unemployed, large young male population, etc.). High offender rates for these areas may reflect subcultural differences in attitudes towards drinking and driving. They may also reflect locational disadvantage. Typically the newer estates possess few licensed premises, with the implication that intending drinkers must travel relatively long distances. Late hour public transport is limited and low incomes mitigate against taxi usage. In addition, most of the estates, planned for virgin broadacre sites, are connected with the city proper by only one or two main roads. These locational factors make policing relatively easy though it is a moot point whether the net result is considered as biassed surveillance

\section{CURRENT OFFENCE AND PRIOR RECORDS}

The offence which caused offenders to become part of the current sample is referred to as the current offence. In Tasmania, driving with a $B A C$ of over $0.05 \%$ constitutes a breach of the law. However, with one exception, the police do not prosecute unless the alcohol reading exceeds $0.06 \%$. The exception relates to first-year drivers (FYD) for whom any blood alcohol constitutes an offence. In fact there are four main alcohol-related driving charges. Thcse are exceeding $0.05 \%$, exceding $0.0 \%$ for FYD. driving under the influence (DUI) and refusing breath analysis (RBA). DUI offenders often come to police attention through erratic driving. Only seven RBA charges emerged in the sample. Most of the RBA offenders were blood tested and eventually also charged with DUI.

Table 3 gives the BAC distribution for the total sample and for persons convicted for FYD and DUJ. Readings under $0.07 \%$ mostly represent FYD but many FYDs had much higher values. Some, in fact, were simuitaneously charged with DUI.

Whilst exceeding a prescribed $\mathrm{BAC}$ is the common element for all offenders, it is not uncommon for people to be simultaneously charged with a number of offences. In all, $34.5 \%$ of offenders were charged with offences in addition to exceeding the prescribed BAC. These additional offences may or may not be alcohol-related. Information on number and type of charges is of significance, since it may contribute to

TABLE 3

\section{Blood Alcohol Concentrations for the Total Sample and for Persons Convicted for FYD and DUI, Hobart 1987*}

\begin{tabular}{|c|c|c|c|}
\hline $\begin{array}{l}\text { BAC } \\
(\%)\end{array}$ & $\begin{array}{c}\text { Total } \\
\text { sample }\end{array}$ & FYD & DUI \\
\hline$<0.07$ & 37 & 29 & 3 \\
\hline 0.07 & 108 & 15 & - \\
\hline 0.08 & 107 & 10 & -. \\
\hline 0.09 & 107 & 7 & 1 \\
\hline 0.10 & 115 & 11 & 4 \\
\hline 0.11 & 102 & 15 & 4 \\
\hline 0.12 & 85 & 12 & 5 \\
\hline 0.13 & 62 & 6 & 2 \\
\hline 0.14 & 56 & 3 & 10 \\
\hline 0.15 & 49 & 8 & 10 \\
\hline 0.16 & 43 & 3 & 5 \\
\hline 0.17 & 43 & 5 & 17 \\
\hline 0.18 & 22 & 2 & 4 \\
\hline 0.19 & 11 & 1 & 5 \\
\hline 0.20 & 14 & - & 5 \\
\hline 0.21 & 10 & $\ldots$ & 5 \\
\hline 0.22 & 5 & - & 2 \\
\hline 0.23 & 8 & 2 & 8 \\
\hline 0.24 & 7 & $\ldots$ & 7 \\
\hline 0.25 & 5 & - & 5 \\
\hline 0.26 & 2 & - & 1 \\
\hline 0.27 & 1 & - & 1 \\
\hline Total & 999 & 129 & 104 \\
\hline
\end{tabular}

* In a few cases, the police record merely indicated $>0.05$. These wercentered as $<0.07$ which explains the discrepancy hetween the FYD and total columns. 
differences in court sentences for people with similar $\mathrm{BACs}$ and prior records. However, description of charge patterns is complicated by various issues. Firstly, a very wide range of combinations is possible. Secondly, some charges generally subsume others. For example, DUY is regarded as more serious than exceeding $0.05 \%$, yet a person may be charged with both. With the exception of FYDs with BACs below $0.07 \%$, all offenders were charged with exceeding $0.05 \%$. Table 4 gives a bald summary of the additional charges, broken down by alcohol-related and other offences.

The tall ies refer to the number of people charged with each offence. Some individuals were charged with several offences in a particular category (c.g. false name and failing to appear in court). A notinconsiderable number were charged with multiple additional offences, with the extreme being an individual charged with RBA, DUI and seven other offences. Not surprisingly, most of the other charges are related to motoring offences. Most common is the "unlicensed" category reflecting offenders who have never been licensed or whose license has been suspended, cancelled or disqualified.

In $8.7 \%$ of all cases, an accident brought offenders to police notice; 49 of these offenders were charged

\section{TABLE 4}

Number of People Charged with Additional Alcohol and Other Offences, Hobart 1987

\begin{tabular}{lr}
\hline Type & No. \\
\hline Alcohol-related offences & 7 \\
RBA & 105 \\
DUI & 131 \\
FYD & 4 \\
Other & \\
(c.g. consuming alcohol in a & \\
moving vehicle) &
\end{tabular}

Other offences*

Driving fault

29

(e.g. fail to stop at red light)

Driving manner

(e.g. negligent driving)

Illegal driving (c.g. unregistered car)

Unlicensed

(e.g. driving whilsi licence disqualified)

Non-traffic offence

(c.g. giving falsc name)

Others and inadequately recorded

* Other offences are classified largely on the system used by Hagger \& Dax (1977). with additional offences, the most common of which was FYD

The prior record of offenders is of major significance to the courts. It is considered here in tems of the number of previous drink driving convictions (priors) and the timing of those offences. Over $42 \%$ of the sample had at least one prior conviction for drink driving (table 5), a finding that contrasts strongly with evidence from elsewhere.

Sanson-Fisher et al. (1986), reviewing Australasian literature, indicate that about $75 \%$ of drink driving convictions are first offences. One other source (House of Representatives Standing Committee on Road Safety 1980) indicates that cventually between $20 \%$ and $25 \%$ of convicted drink drivers are reconvicted for the same offence. Possibly the method of data collection was biassed towards repeat offenders but, even with some bias, the figures suggest a higher proportion of multiple offenders in Tasmania than the national norm. This may indicate greater recidivism and/or more thorough policing in that State.

The temporal pattern of priors shows a wide range of variants on a theme. Figure 1 and tables 6 and 7 give part of the picture. Over $20 \%$ of all recidivists had had their most recent prior within about 18 months of their current conviction, and $50 \%$ within about three years. Conversely, a small proportion of recidivists $(10.4 \%)$ showed relatively long arrestfrec periods, with their most recent prior being before 1980. The highest proportion of very recent offences was crident for those with more than two priors. Of offenders with more than one prior, exactly half had first convictions dating from before 1980, which suggests relatively long participation in drink driving.

From discussions with police and convicted offenders, it is clear that there is enormous variation

TABLE 5

Prior Convictions for Drink Driving Offences, Hobart 1987

\begin{tabular}{lcc}
$\begin{array}{l}\text { Number } \\
\text { of } \\
\text { priors }\end{array}$ & No. Offenders \\
\hline 0 & 571 & $\%$ \\
1 & 235 & 57.1 \\
2 & 112 & 23.5 \\
$>2$ & 82 & 11.2 \\
& & 8.2 \\
\hline
\end{tabular}


TABLE 6

Date of Most Recent Offence for Recidivists, Hobart 1987

\begin{tabular}{|c|c|c|c|c|c|c|c|c|}
\hline \multirow{3}{*}{$\begin{array}{l}\text { Year } \\
\text { of } \\
\text { Conviction }\end{array}$} & \multicolumn{8}{|c|}{ Number of previous offences } \\
\hline & \multicolumn{2}{|c|}{ One } & \multicolumn{2}{|c|}{ Two } & \multicolumn{2}{|c|}{$>$ Two } & \multicolumn{2}{|c|}{ Total } \\
\hline & No. & $\%$ & No. & $\%$ & No. & $\%$ & No. & $\%$ \\
\hline $1986 / 7$ & 52 & 22.2 & 17 & 15.2 & 22 & 26.8 & 91 & 21.0 \\
\hline 1985 & 45 & 19.2 & 20 & 17.8 & 11 & 13.4 & 76 & 17.5 \\
\hline 1984 & 40 & 17.1 & 20 & 17.8 & 17 & 20.7 & 77 & 18.4 \\
\hline 1983 & 26 & 11.1 & 15 & 13.4 & 9 & 11.0 & 50 & 11.5 \\
\hline 1982 & 11 & 4.7 & 12 & 10.7 & 8 & 9.8 & 31 & 7.1 \\
\hline 1981 & 13 & 5.6 & 5 & 4.5 & 10 & 12.2 & 28 & 6.5 \\
\hline 1980 & 8 & 3.4 & 6 & 5.4 & 1 & 1.2 & 15 & 3.5 \\
\hline Before 1980 & 31 & 13.3 & 11 & 9.8 & 3 & 3.7 & 45 & 10.4 \\
\hline Not recorded & 8 & 3.4 & 6 & 5.4 & 1 & 1.2 & 15 & 3.5 \\
\hline Total & 234 & 100.0 & 112 & 100.0 & 82 & 100.0 & 428 & 100.0 \\
\hline
\end{tabular}

TABLE 7

Date of Earliest Offence for Multiple Offenders, Hobart 1987

\begin{tabular}{lccc}
\hline $\begin{array}{l}\text { Year } \\
\text { of }\end{array}$ & \multicolumn{3}{c}{ Number of Previous Offences } \\
Conviction & Two & $>$ Two & Total \\
\hline $1986 / 7$ & 2 & 1 & 3 \\
1985 & 9 & 1 & 10 \\
1984 & 5 & 3 & 8 \\
1983 & 14 & 2 & 16 \\
1982 & 11 & 6 & 17 \\
1981 & 9 & 5 & 14 \\
1980 & 10 & 8 & 18 \\
Before 1980 & 44 & 53 & 97 \\
Not recorded & 8 & 3 & 11 \\
& & & \\
Total & 112 & 82 & 193 \\
\hline
\end{tabular}

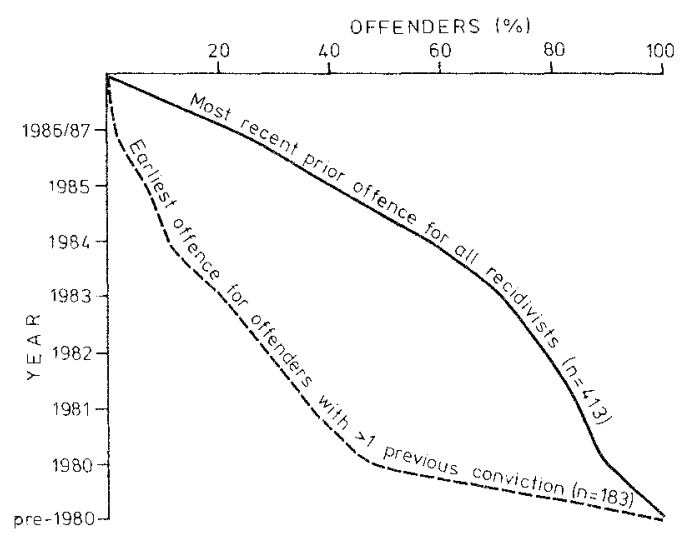

FIG. I - Timing of previous offences. The data exclude 16 persons for whom a prior record was known to exist but for whom specific details were not available. 
in case histories. People with two convictions range from the genuinely unlucky -.-. represented, perhaps, by the individual who has driven over the limit twice in ten years and been caught on both occasions -through to those who are just beginning to compile what willeventually be a long record. The history of the most convicted person in the smole indicates the alcoholic end of the spectrum (table 8). First convicted in 1972, this now unemployel, 37-yearold male had collected 11 priors before entering the sample with a BAC of $0.17 \%$ and charges of DUl and driving whilst still suspended for previous offences.

Associated with increased numbers of priors are average offences at higher levels (table 9). Many of the multiple offenders would appear to have alcoholrelated problems that are immune to affect by current punishment and treatment systems. These offenders, it must be recalled, represent the caught and convicted. Behind them is a group of unknown size that has managed to avoid frequent detection.

\section{ENTRY TO THE COURT SYSTEM}

The time lag between arrest and conviction (table 10) indicates that most offenders are processed relatively quickly by the courts. The mean lag is 47 days but this is heavily influenced by a small number of cases with very long delays. Over a quarter of offenders were sentenced within 20 days and over a half in 40 days, emphasising the routine nature of drink driving cases. Longer delays usually reflect offenders who,

TABLE 8

\section{Drink Driving Record of the Most Convicted Offender}

\begin{tabular}{lcl}
\hline Date & BAC $(\%)$ & Additional charges* \\
31.3 .73 & 0.13 & \\
26.1 .74 & 0.22 & DUI \\
1.2 .74 & 0.15 & DUI \\
10.11 .74 & 0.15 & - \\
17.4 .77 & 0.17 & DUI \\
23.12 .78 & 0.17 & - \\
9.6 .79 & 0.16 & DUS \\
10.10 .82 & 0.10 & DUS \\
28.5 .83 & $>0.05$ & DUS \\
21.10 .83 & 0.18 & DUI, FYD, DUS, false name \\
23.4 .85 & 0.15 & DUI, false name \\
\hline
\end{tabular}

* DUS $=$ Driving under suspension commonly on advice from a solicitor, have sought adjournments.

Once charged the next decision lor many is whether to retain a solicitor. Petersen (1983), from a study in WA, indicates that about $25 \%$ of his sample hired a lawyer. He atribures the relatively low level ol representation to the quantiative evidence of drink driving, seen by most oflenders as unambigumes. Most, he daims, whin momimise the stress and expense of contesting a case and to get it "over and done with" as soon as possible. In comrast, about two-thirds of the Tasmanian sample was tepresented (table 11 ). The proportion increases win number of priors and varies in a logical manner with occupalional category (iable 2). In this context, it is worth noting that legal aid is not available for

TABLE 9

Number of Prior Offences, Average $\mathrm{BAC}$ Level and High BACs

\begin{tabular}{lcccc}
\hline $\begin{array}{l}\text { Number of } \\
\text { priors }\end{array}$ & $\begin{array}{c}\text { No. of } \\
\text { persons }\end{array}$ & $\begin{array}{r}\text { Mean BAC } \\
\text { (\%) of } \\
\text { current } \\
\text { offence }\end{array}$ & $\begin{array}{c}\text { No. of } \\
\text { offenders }\end{array}$ & $\%$ \\
\hline None & 571 & 0.11 & 89 & 15.5 \\
One & 234 & 0.12 & 53 & 22.6 \\
Two & 112 & 0.13 & 37 & 33.3 \\
>Two & 82 & 0.14 & 41 & 50.0 \\
\hline
\end{tabular}

TABLE 10

Time Lag Between Arrest and Conviction

\begin{tabular}{ccc}
$\begin{array}{c}\text { Number } \\
\text { of days }\end{array}$ & No. & $\%$ \\
& & \\
\hline$<$ & 229 & 26.9 \\
$20-39$ & 243 & 28.6 \\
$40-59$ & 157 & 18.4 \\
$60-79$ & 80 & 9.4 \\
$80-99$ & 64 & 7.5 \\
$100-149$ & 55 & 6.5 \\
$150-199$ & 12 & 1.4 \\
$200-299$ & 10 & 1.2 \\
$>300$ & 1 & 0.1 \\
Total & 851 & 100.0 \\
\hline
\end{tabular}


TABLE 11

Legal Representation and Prior Record

\begin{tabular}{lrrr}
\hline $\begin{array}{l}\text { Number } \\
\text { of priors }\end{array}$ & Number & \multicolumn{2}{c}{ Representation } \\
& & No & $\%$ \\
None & 571 & 371 & 65.0 \\
One & 235 & 155 & 66.0 \\
Two & 112 & 81 & 72.3 \\
>Two & 82 & 67 & 81.7 \\
Total & 1000 & 674 & 67.4 \\
\hline
\end{tabular}

defendants appearing on traffic charges unless there is a likelihood that the defendant will be jailed.

Amongst offenders, both first and recidivist, there is a belief that solicitors "know the system" and may be able to achieve a more favourable result by steering their client to an appropriate magistrate. The steering mechanism is discussed further below. One magisterial source has indicated that legal representation, by increasing court efficiency, warrants a small "discount". The reasoning is that in hiring a lawyer, offenders already incur a substantial cash outlay. Hence, any court fine might be reduced by a small amount. Whatever the reasoning, it is clear that drink driving offences generate substantial flows of money to the legal profession.

Client steering operates through adjournments which mean that a scheduled court appearance is postponed. Postponement may be by the magistrate or on the application of the offender or, more usually, a solicitor or the police. Adjournments can occur for many reasons but here only the number for each case is considered. Overall, $42.7 \%$ of the cases were adjournment free (table 12). However, less than half of first offenders were sentenced without adjournments whilst more than two-thirds of those with more than one prior had adjournments (table 12 ). Multiple offenders also had higher proportions of multiple adjournments. To a large extent, the delays caused by adjournments are responsible for the variations in arrest/conviction times.

Various factors lie behind decisions to request, or not request, adjournments. As noted above, some may wish to have their case finalised quickly. Adjournments may not be sought by some multiple offenders because they view their position with a sense of resignation. In some instances, adjournments are sought to prepare a case for an ancillary offence, particularly those of a non-routine nature.

Adjournments may be requested to gain appearance before a particular magistrate perceived to be either generally more "Ienient" or more likely to treat specific categories of offender more leniently. There is ample evidence from the mainland to show that the sentencing styles of individual magistrates vary in identifiable ways (for example, Homel 1983). In Tasmania, there are statistically significant differences in the sentences handed down by the three benches of the Lower Court (Wood 1989b). Comment from people with regular and frequent contact with the courts (press and police) indicates that some individual magistrates are seen as "soft". Retaining a solicitor buys this knowledge and adjournments are the means by which clients may be

TABLE 12

Number of Adjournments by Number of Priors

\begin{tabular}{|c|c|c|c|c|c|c|c|c|c|c|c|c|}
\hline \multirow{4}{*}{$\begin{array}{l}\text { No. } \\
\text { of } \\
\text { priors }\end{array}$} & \multicolumn{12}{|c|}{ Number of adjournments } \\
\hline & \multicolumn{4}{|c|}{ None } & \multicolumn{2}{|c|}{2} & \multicolumn{2}{|c|}{3} & \multicolumn{2}{|c|}{$>3$} & \multicolumn{2}{|c|}{ Total } \\
\hline & No. & $\%$ & No. & $\%$ & No. & $\%$ & No. & $\%$ & No. & $\%$ & No. & $\%$ \\
\hline & $\cdots-$ & -... & - & $\ldots$ & & 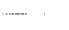 & $\ldots$ & & & & 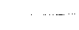 & \\
\hline 0 & 275 & 48.2 & 186 & 32.6 & 75 & 13.1 & 23 & 4.0 & 12 & 2.1 & 571 & 100.0 \\
\hline 1 & 93 & 39.6 & 82 & 34.9 & 32 & 13.6 & 17 & 7.2 & 11 & 4.7 & 235 & 100.0 \\
\hline 2 & 35 & 31.3 & 30 & 26.8 & 26 & 23.2 & 12 & 10.7 & 9 & 8.0 & 112 & 100.0 \\
\hline$>2$ & 24 & 29.3 & 25 & 30.5 & 13 & 15.9 & 11 & 13.4 & 9 & 11.0 & 82 & 100.0 \\
\hline Total & 427 & 42.7 & 323 & 32.3 & 146 & 14.6 & 63 & 6.3 & 41 & 4.1 & 1000 & 100.0 \\
\hline
\end{tabular}


guided to a suitable appearance. It should be stressed that decisions about which offenders appear before each magistrate are made by the Clerk of the Court. Magistrates have no input.

In some instances, adjournments can be of value to an offender by delaying sentencing. This applies particularly with applications for restricted licences where the law stipulates that applicants must have a three-year period free from conviction for an alcoholrelated driving offence. The period is measured not from arrest to arrest but from conviction to conviction, hence delays may be of benefit in some cases.

With current data, it is impossible to make more than inferences about the extent or targets of manoeuvring through adjournments. Certainly the number of drink driving cases heard by each magistrate varied markedly (table 13). One magistrate heard $23 \%$ of the cases, with most of the others handling between $11 \%$ and $15 \%$. The apparently unequal division of hearings could reflect specialisation amongst the magistrates. Alternatively, it could be taken to illustrate steering of cases since, as is shown later, the magistrate who heard the most cases also made greatest use of the lightest penalties. More detail for specific sequences of adjournments would be necessary to explore this issue further.

\section{THE OUTCOMES}

Not surprisingly, the issue of most concern to offenders is the court decision. A variety of sentencing options is open to the courts. At the time of the survey, the main options were as follows:

TABLE 13

Number of Cases Heard by Each Magistrate

\begin{tabular}{lc}
\hline Magistrate & Cases \\
\hline A & 230 \\
B & 147 \\
C & 144 \\
D & 116 \\
E & 113 \\
F & 81 \\
G & 149 \\
& \\
Total & 1000 \\
\hline
\end{tabular}

(1) Demerit Points (DPs). These are ascribed to an offender's licence. Accumulation of nine DPS in three years leads to loss of licence for a specified period. DPs can also be awarded for other motoring offences.

(2) Fines. Occasionally all or part of a fine may be suspended on condition that no further breach of the law is commifted within a set period.

(3) Licence Disqualification. Again, this may be delayed. When a person's livelihood is dependent on possession of a driver"s licence, a restricted licence may be granted. This permits driving on certain routes at certain times.

(4) Community Service Orders (CSOS). A CSO requires an offender to work on a designated project for a specified number of hours. Only given with the consent of the offender, CSOs are often used in lieu of a fine.

(5) Suspended Jail Sentence (SS). A jail term suspended on condition that the offender commit no breach within a specified time.

(6) Jail.

Magistrates require all FYDs to attend a prescribed course that outlines the dangers of drinking and driving. On very rare occasions, they may also require attendance at an alcohol rehabilitation centre.

Details of the total penalties handed down for the sample are given in table 14. These bald figures indicate that fines and disqualifications, usually imposed in combination, are by far the most common penalty elements. DPs, at the time of the survey usually given with a fine to older offenders with low $\mathrm{BACs}$ and relatively clean records, were awarded in about $6 \%$ of cases. CSOs were allocated to about

\section{TABLE 14 \\ Total, Range and Mean Penalties}

\begin{tabular}{lrrrrr}
$\begin{array}{l}\text { Type of penalty } \\
\text { and units }\end{array}$ & \multicolumn{4}{c}{ Penalty } \\
& $\begin{array}{c}\text { No. } \\
\text { of } \\
\text { offenders }\end{array}$ & Total & \multicolumn{2}{c}{ Range } & Mean \\
& & & Min. & Max. \\
\hline DPs (number) & 59 & 229 & 1 & 4 & 3.9 \\
Fine (\$)* & 896 & 150746 & 30 & 500 & 168.2 \\
Disqual.(months) & 942 & 10485 & 1 & 60 & 11.1 \\
CSO (hours) & 48 & 3853 & 25 & 180 & 80.3 \\
SS (days) & 64 & 2333 & 7 & 180 & 36.5 \\
Jail (days) & 33 & 2754 & 7 & 365 & 83.5 \\
Restricted licences & 69 & & & &
\end{tabular}

\footnotetext{
* Does not include court costs
} 
$5 \%$. The more severe sanctions of SS and jail formed part of the penalty of $6.4 \%$ and $3.3 \%$ respectively.

The magnitude of the total sentences gives some indication of the effects that drink driving has on people's lives and on state services. This sample containing about $20 \%$ of the state's annual drink driving convictions, generated fines of over $\$ 150000$, cancelled driving licences for over 870 years and put people in jail for a combined total of 7.5 years. In addition to the direct effects for police, court, prison and probation staff, a drink driving conviction can also have social, familial and employment implications.

The sentencing options, as listed at the start of this section, can be seen in terms of an ascending severity ladder (Sparks 1971). To examine court decisions more closely, the package of penalties awarded to each offender was classified according to its most severe element. For example, a sentence involving DPs and a fine was classified as 'Fine', etc.

There is considerable public disquiet over perceived disparities in sentences handed down for apparently similar offences. A common magisterial response is that the public generally is unaware of all the facts associated with any particular case. In particular, the importance of prior records is stressed. The rest of this section examines sentences in terms of prior records and by magistrate.

\section{Priors and Sentences}

Cross tabulation of type of sentence by number of priors indicates that, generally, recidivists received more severe sentences than first offenders (table 15). Entries away from the broad diagonal generally reflect particular circumstances. For example, the
TABLE 15

Type of Sentence and Prior Record

\begin{tabular}{lccccc}
\hline $\begin{array}{l}\text { Number } \\
\text { of priors }\end{array}$ & \multicolumn{5}{c}{ Most severe element in penalty } \\
& Fine & Disq. & CSOS & Ss & Jail \\
\hline 0 & 50 & 502 & 11 & 5 & 3 \\
1 & 2 & 211 & 8 & 10 & 4 \\
2 & 0 & 72 & 15 & 19 & 6 \\
$>2$ & 0 & 23 & 11 & 27 & 21 \\
\hline
\end{tabular}

two offenders with one prior for whom the most severe penalty element was a fine both had low BACs $(<0.09 \%)$ and a long arrest-free period ( $>7$ years). Conversely, of the three first offenders who were jailed, two had multiple ancillary offences including breach of bail and damaging police property.

Just as penalty severity increases with number of priors, so does the average quantity of each sentence element (table 16). An increase in the mean penalty from first offenders through to multiple recidivists is evident for all sentence elements except jail, where the numbers in most categories are very small.

An obvious inference is that magistrates use priors as a guide for penalty type and amount. Progression up the ladder of priors carries with it the strong likelihood of larger amounts of successively more severe penalties. It has to be stressed, however, that these are gross figures obtained by summing the decisions of all magistrates. The following section disaggregates sentences to the level of the individual magistrate.

TABLE 16

Mean Sentences by Prior Record

\begin{tabular}{|c|c|c|c|c|c|c|c|c|c|c|c|}
\hline \multirow{2}{*}{$\begin{array}{l}\text { Number } \\
\text { of priors }\end{array}$} & \multirow{2}{*}{$\begin{array}{l}\text { Number } \\
\text { receiving } \\
\text { DPs }\end{array}$} & \multicolumn{2}{|c|}{ Fine } & \multicolumn{2}{|c|}{ Disq. } & \multicolumn{2}{|c|}{ CSO } & \multicolumn{2}{|c|}{ SS } & \multicolumn{2}{|c|}{ Jail } \\
\hline & & No. & $\begin{array}{c}\text { Mean } \\
(\$)\end{array}$ & No. & $\begin{array}{l}\text { Mean } \\
\text { (mths) }\end{array}$ & No. & $\begin{array}{c}\text { Mean } \\
\text { (hrs) }\end{array}$ & No. & $\begin{array}{l}\text { Mean } \\
\text { (days) }\end{array}$ & No. & $\begin{array}{r}\text { Mean } \\
\text { (days) }\end{array}$ \\
\hline 0 & 56 & 555 & 146.7 & 520 & 6.5 & 11 & 58.7 & 5 & 22.2 & 3 & 94.0 \\
\hline 1 & 3 & 220 & 197.8 & 233 & 12.3 & 8 & 67.1 & 10 & 24.1 & 3 & 74.7 \\
\hline 2 & 0 & 83 & 205.3 & 110 & 17.6 & 17 & 85.2 & 19 & 34.3 & 6 & 56.7 \\
\hline$>2$ & 0 & 38 & 230.8 & 79 & 29.4 & 12 & 101.8 & 30 & 44.3 & 21 & 90.8 \\
\hline
\end{tabular}




\section{The Magistrate Factor}

In terms of sentence types (table 17), all magistrates showed a strong preference for packages in which the most severe element was disqualification. This was almost always acconpanied by a fine. Table if suggests that some magistrates use particular penally types disproportionately. For example, more than two-thirds of the lightest penalty type (fine plus DPs) were handed down by just two of the magistrates (A and C). Similarly, E alone gave $40 \%$ of the CSO penalties whilst D, E and $\mathrm{G}$ appear under-represented for suspended sentences. Numbers in most of the cells of table 17 are too small to make stronger statements but there are sufficient indications of disparities to warrant more detailed examination of the major penalty lype - that of a fine/disqualification combination.

Table 18 classifies these combinations in order of increasing severity from a disqualification of less than four months and a fine of less than $\$ 100$ at the bottom of the scale through to disqualifications exceeding 18 months and all fines at the other extreme. These data relate only to offenders who received a fine/disqualification penalty and to the seven permanent magistrates. Seen in simple statistical terms, there is a highly significant difference between the magistrates $\left(\chi^{2}=223.8\right.$, d.f. $=60, p=<0.0001)$. Various under- and overrepresentations contribute to the difference. Major features are as follows:
TABLE 17

Individual Magistrate and Type of Sentence

\begin{tabular}{|c|c|c|c|c|c|c|}
\hline \multirow{2}{*}{$\begin{array}{l}\text { Magis- } \\
\text { Irate }\end{array}$} & \multicolumn{6}{|c|}{ Most severe element in probalty } \\
\hline & Mues & Disa. & $(2,50)$ & 58 & Auth & Cotal \\
\hline$A$ & 21 & 177 & 5 & 20 & ? & 230 \\
\hline $\mathrm{B}$ & 2 & 123 & 2 & 15 & 5 & 147 \\
\hline$C$ & 15 & 108 & 5 & 10 & 6 & 144 \\
\hline$D$ & 1 & 101 & 8 & 1 & 5 & 116 \\
\hline $\mathrm{E}$ & 1 & 80 & 18 & 4 & 4 & 113 \\
\hline $\mathrm{F}$ & 5 & 62 & 2 & 10 & 2 & 81 \\
\hline$G$ & 7 & 134 & 4 & 1 & 3 & 149 \\
\hline Other & 0 & 17 & 1 & 0 & 2 & 20 \\
\hline Total & 52 & 808 & 4.5 & 61 & 34 & 1000 \\
\hline
\end{tabular}

- Magistrate A, already identified as having the largest number of cases and handing down the largest proportion of the lightest type of penalty (fine plus DPs), also shows the highest proportion of all the lightest fine/disqualification sentences. Over half of his sentences $(51.4 \%)$ were in the three lowest categories, compared to less than a third for D, F and G.

- Magistrate G shows a heavy concentration in the range from 4 to 9 months. Over $70 \%$ of his sentences were in this range, compared to less than one-third for $D$.

TABLE 18

Fine/Disqualification Penalties by Magistrates

\begin{tabular}{|c|c|c|c|c|c|c|c|c|c|c|}
\hline \multicolumn{3}{|c|}{$\begin{array}{l}\text { Fine/ } \\
\text { disqualification } \\
\text { combination }\end{array}$} & \multicolumn{8}{|c|}{ Magistrate } \\
\hline mths & + & $\$$ & A & B & $C$ & D) & $\mathrm{E}$ & I & C & Total \\
\hline $1-3$ & & $0-100$ & 34 & 22 & 6 & 4 & 2 & 0 & 9 & 77 \\
\hline $1-3$ & & $>100$ & 20 & 8 & 11 & 17 & 10 & 10 & 5 & 81 \\
\hline $4-6$ & & $0-150$ & 37 & 32 & 25 & 12 & 25 & 9 & 30 & 170 \\
\hline $4-6$ & & $>150$ & 7 & 8 & 5 & 8 & $1+$ & 12 & 25 & 79 \\
\hline $7-9$ & & $0-150$ & 13 & 3 & 7 & 9 & 2 & 4 & 2.1 & 59 \\
\hline $7-9$ & & $>150$ & 7 & 8 & 10 & 4 & 12 & c) & 20 & 70 \\
\hline $10-12$ & & $0-200$ & 20 & 21 & 21 & 9) & 4 & 2 & 6 & 83 \\
\hline $10-12$ & + & $>200$ & 5 & 6 & 6 & 5 & 7 & 9 & $\varsigma$ & 43 \\
\hline $13-18$ & & $0-200$ & 20 & 3 & 0 & 15 & 4 & 1 & 2 & 4.5 \\
\hline $13-18$ & & $>200$ & 9 & 7 & 8 & 7 & 4 & 2 & 6 & 43 \\
\hline$>18$ & & all fines & 5 & 5 & 8 & 11 & 4 & 4 & 5 & 42 \\
\hline Total & & & 177 & 123 & 107 & $10 \mathrm{i}$ & 88 & 62 & 134 & 792 \\
\hline
\end{tabular}


- Magistrates A, B, and C appear over-represented in the 10.12 nonths and more than $\$ 200$ category. - Almost one-third of D's sentences were in the highest threc categories. None of the others exceeded $20 \%$ and one. $G$, scored less than $10 \%$.

Whilst this evidence may be taken to indicate disparities in sentencing, it could be argued that the differences reflect the specific circumstances of the cases heard by each magistrate. Further insight can be obtained by selecting out offenders within specific categories. Table 19 provides data for males under 25 , with no priors and a current BAC of less than $0.11 \%$. Selection to meet these criteria produced 123 offenders; lunther breakdown by magistrates gives small numbers that only permit inferences. In all but a few cases, magistrates awarded a fine/disqualification penalty. The two who were jailed both had serious ancillary offences. In terms of fines, magistrate $A$ again appears at the lenient end of the scale with the lowest average, minimum and maximum fines. His average fine was only $55 \%$ of that of magistrate $G$. The picture with regard to disqualification periods is less clear, though the highest average (D) exceeds the lowest (B) substantially.

It seems clear that individual magistrates in southern Tasmania differ substantially in their treatment of essentially similar cases. The existence of disparities is not surprising, given that the phenomenon has been widely reported elsewhere (for example, Homel 1983), but it has not previously been subject to detailed examination in Tasmania.

\section{DISCUSSION}

The public tends to view drink driving cases as clear cut. Guilt is rarely in question and a breathalyser reading gives incontrovertible evidence of the degree of transgression. The public expects that similar transgressions will be punished by the courts in a consistent fashion. Yet it is clear from the evidence presented here that sentencing disparities between benches in Tasmania (Wood, 1989b) are matched at the level of the individual magistrate. Who hears one's case can have a significant effect on the type and amount of sanction that is imposed.

It would seem that the current system of handling drink driving cases would benefit from review. Two alternatives, with many intermediates, can be outlined. One involves maintenance of the status quo. This implies that sentencing is and should be a highly individual affair. It accepts that magistrates can and should vary a sentence to suit the specific circumstances of both offender and offence.

TABLE 19

Sentences for Young, Male, First Offenders with Current BAC of Less than $0.11 \%$ by Magistrate

\begin{tabular}{|c|c|c|c|c|c|c|c|c|}
\hline \multirow[t]{2}{*}{ Penalty } & \multicolumn{7}{|c|}{ Magistrate } & \multirow[b]{2}{*}{ Other } \\
\hline & $A$ & B & C & D & $\mathbf{E}$ & $\mathbf{F}$ & $G$ & \\
\hline \multicolumn{9}{|l|}{ Type } \\
\hline Fine & 1 & -- & 2 & - & - & - & - & - \\
\hline Disq. & 20 & 27 & 14 & 13 & 12 & 10 & 17 & 3 \\
\hline $\operatorname{CsO}$ & - & - & - & - & 1 & - & - & - \\
\hline SS & - & 1 & $\ldots$ & - & - & - & - & - \\
\hline Jail & $\cdots$ & - & - & - & 1 & - & 1 & - \\
\hline Total & 21 & 28 & 16 & 13 & 14 & 10 & 18 & 3 \\
\hline \multicolumn{9}{|l|}{ Fine $(\$)$} \\
\hline average & 96.2 & 102.7 & 119.4 & 154.2 & 162.3 & 167.8 & 174.7 & 156.7 \\
\hline number & 21 & 27 & 16 & 13 & 13 & 9 & 18 & 3 \\
\hline mininumar & 30 & 50 & 60 & 75 & 100 & 100 & 75 & 110 \\
\hline maximum & 150 & 250 & 235 & 250 & 240 & 350 & 260 & 200 \\
\hline \multicolumn{9}{|c|}{ Disqualification (months) } \\
\hline average & 5.0 & 3.8 & 4.6 & 7.1 & 4.1 & 5.7 & 5.9 & 4.0 \\
\hline number & 20 & 28 & 14 & 14 & 14 & 10 & 18 & 3 \\
\hline minimum & 1 & 2 & 1 & 2 & 2 & 2 & 3 & 3 \\
\hline maximum & 15 & 12 & 12 & 15 & 9 & 18 & 9 & 6 \\
\hline
\end{tabular}


However, the current system has aspects that may be viewed as disadvantageous and/or unjust. There is no doubt that it absorbs large public expenditures for what has become a routine charge. The current system encourages manoeuvring through adjournments which many regard as inequitable. A detailed knowledge of magistrates' sentencing styles, gained from court experience, is a major service that solicitors can offer to their clients. As has often been noted (for example, Hood 1972), sentencing disparities contribute to public disatisfaction with the courts and, by implication, the police.

Against this background, many have argued for revisions of the legal system particularly with reference to high frequency offences such as drink driving. Perhaps the most advocated alternative is for a "... network of prescribed sentences based on type of offence and offender's criminal record" (Ashworth 1970: 47). Homel's (1983) suggestion for sentencing drink drivers is that a two-way grid be drawn up in which one axis comprises BAC values (reflecting the seriousness of the current offence) and the other indicates previous drink driving and other motoring convictions (reflecting the blameworthiness of the offender). He advocates a range of penalties for each cell that is sufficiently broad to accommodate mitigating factors (such as unemployment) but much narrower than those currently evident in sentencing statistics.

This is not the place and the author is not the person to propose cut off points within such a grid. Difficult decisions on many questions would need to be made, including definitions of mitigating factors, procedures for handling ancillary offences, etc. Yet, properly researched and implemented, a sentencing system based on specified guidelines appears to have many advantages. It, presumably, would reduce community disquiet with the current system. It would give magistrates a firmer frame of reference. It might reduce public expenditure by increasing court efficiency. People with close contact with the system indicate that the "penalty" most disliked by many offenders is publication of their name and offence details in the press. Providing that this requirement is maintained, it may be worth exploring the option of automatic penalties that do not require court appearances for standard offences.

This research suggests that at least three other matters require consideration by the legislators. Firstly, if steering through adjournments is seen to be undesirable, an option may be to require that adjournments are granted only on condition that the defendant reappear before the initial magistrate; this, in turn, might require some revision of court procedures. Secondly, the legislation relating to the dating of arrest-free periods for restricted license applicants would benefit from review. Thirdly and most importantly, this study shows that recidivism is at a disturbingly high level in southern Tasmania. One implication is that current sanctions do not have a strong deterrent effect for many offenders. Additional procedures, not necessarily involving harsher penalties, need to be institured for repeat offenders. An option may be to extend use of the P plate system requiring, say, people convicted more than once to carry $P$ plates for a specified period.

Whether the current system is revised or not, one important issue remains to be discussed. There is a clear and urgent need for more information about court decisions. Such information would contribute to better public understanding of the system. It would also allow magistrates to compare standards. At present, there is no regular monitoring of court decisions. Such information could be used to identify and correct apparent discrepancies. It would also form a vital ingredient for any revision of the system.

\section{ACKNOWLEDGEMENTS}

The author wishes to thank the Tasmanian Police Department for assistance in data collection. The comments of many people on drafts of this paper are also acknowledged.

\section{REFERENCES}

\section{ABS, 1986: LOWER COURT STATISTICS TASMANIA} 1986.

Andenaes, J., 1974: PUNISHMENT AND DETERRENCE. University of Michigan Press, Ann Arbor.

Ashworth, A. 1987: Criminal justice, rights and sentencing: a review of sentencing policy and problems. In Potas, I. (Ed.): SENTENCING IN AUSTRALIA. Australian Institute of Criminology and Australian Law Reform Commission, Seminar No. 13. Australian Institute of Criminology, Canberra: $35-73$.

CASHMORE, J., 1985: THE IMPACT OF RANDOM BREATH TESTING IN NSW. Research Study No. 4. New South Wales Bureau of Crime Statistics and Research, Attorney General's Department, Sydney.

HAGGeR, R. \& DAX, E.C., 1977: The driving records of multiproblem families. Social Science and Medicine 11: 121-127

Homel, R., 1981: Penalties and the drink driver: a study of one thousand offenders. Aust. N.Z. J. Criminol. 14: 225-241.

Homel, R., 1983: Sentencing in magistrates' courts: some lessons from a study of drinking drivers. In Findlay, M., Egger, S.J. \& Sutton, J. (Eds): ISSUES IN 
CRIMINAL JUSTICE ADMINISTRATION. AIJEN \& Unwin, Sydney: 109-125.

HOMEL, R., 1986: POLICING TIIE DRINKING DRIVER: RANDOM BREATH TESTING AND THE PROCESS OF DETERRENCE. Federal Office of Road Safely, Sydney.

HOOD, R., 1972: SENTENCING THE MOTORING OFFENDER. Heinemann, London.

Holse of Representatives Standing Commette on Ron SAFETY, 1980. ALCOHOL, DRUGS AND ROAD SAFETY. Report. Canberra.

KenNedy, B.G., Wood, L.J. \& CoTgrove, R.D.M., 1989: A SOCIAL ATLAS OF METROPOLITAN HOBART. Department of Geography and Environmental Studies, University of Tasmania.

Lovegrove, A., 1987: An evaluation of judicial models for sentencing guidelines. In Potas, I. (Ed.): SENTENCING IN AUSTRALIA. Austratian Institute of Criminology and Australian Law Reform Commission, Seminar No. 13. Australian Institute of Criminology, Canberra: 211-221.

MAdDEN, B., 1986: Random breath testing (RBT) in Tasmania. Paper presented at the First Road Safety Initiatives Conference, Melbourne.
PETERSEN, A.R., 1983: Drink drivers and the judicial process: an analysis that relates to the defendant's perspective, Aust. J. Sor. Isste's 18: 18 -32.

SAvSON-Fisher, R., Rromax, S. \& OSWOSD, C. 1986: REHABILITATION OF DRINK DRIVERS IN AUSTRALIA AND NEW ZEALAND. Federal Department of Transport. Federal Office of Roud Sufety, C.R. No. 43. Canberra.

SiKk, E., 1985. Avolding delay in magistrales courts. Unpubl, mantiscripi, Hobart.

Sparks, R. 1971. The use of suspended sentences, Cim. Law Rev: $384-401$.

Woov, L.J., 1987. Drink driving offenders and penahilies in metropolitan Hobart. Aust. Geogr. Suad. 25: 15 35 .

WooD. L.J., 1989a: Drink driving offender rates in Tasmania. Aust. Geogr. 20: 74-79.

Woov, L.J., 1989b: Disparities in court sentences: a Tasmanian perspective. Aust. Geogr. Stud. 27:87-. 97.

(accepted 2 February 1990) 